\title{
Community-Based Disaster Communication Management
}

\author{
MOCHAMAD ROCHIM \\ Universitas Islam Bandung, Indonesia \\ ATWAR BAJARI \\ NINIS AGUSTINA DAMAYANI \\ IRIANA BAKTI \\ Universitas Padjadjaran, Jatinangor, Indonesia
}

\begin{abstract}
Indonesia is a country that is prone to disasters. To this relation, the government has created the National Disaster Management Agency (BNPB) and the Regional Disaster Management Agency (BPBD) in almost all provinces. However, the magnitude of the potential for disaster causes the government to feel the need for community support in disaster mitigation efforts. Community participation is absolutely necessary. It is in this context that the emergence of the community, in this case, the Garda Caah, is important. With the motto "Hope for the best, prepare for the worst," this community tries to help residents in flood prevention efforts and minimize the impact of flooding by providing immediate and continuous information. The aspect of managing communication and information is the most important part of this community. This study uses a qualitative method with a case study approach. The data collection techniques were carried out by interview, focus group discussion, and observation. There are two main results of this study namely (1) self-management of flood disaster anticipation based on the learning process, empowerment and volunteer activities, (2) the transition of traditional information systems that are modest to a new information system that is based on technology.
\end{abstract}

Keywords: Community, Garda Caah, participatory communication management, disaster.

\section{INTRODUCTION}

In Indonesian Disaster Management Law No. 24 of 2007, disaster is defined as a series of events that threaten and disrupt the life and livelihoods of the community, which are caused either by natural factors and/ or non-natural factors as well as human factors, resulting in human casualties, environmental damage, property loss, and psychological impact (UndangUndang Republik Indonesia, 2017). Based on data from the National Disaster Management Agency (BNPB) in the period of January 1 to July 1, 2020, there were 1,557 disaster events, which were dominated by floods, tornadoes and landslides. The disaster resulted in 2,326,092 displaced people and 206 people passing away and 273 were injured. Especially in Bandung Regency, every heavy rain will cause the Citarum River and its tributaries to overflow. The result is fatal, as in early 2020 there were at least 10,000 houses in nine sub-districts were flooded with a height of up to 3 meters. The nine sub-districts are Bojongsoang, Baleendah, Dayeuhkolot, Kutawaringin, Solokanjeruk, Ciparay, Cangkuang, Majalaya, and Rancaekek (Sinaga, 2020). According to Kompas (a nationally reputable newspaper) records, flooding in Bandung Regency generally occurs because the bend in the overflowing river has resulted in densely populated settlements on the banks of the river being submerged with varying depths of up to 1.5 meters, for example in Majalaya. "The flood in Majalaya has a heavy current and lasts about eight hours because it is a trajectory area. In fact, this is dangerous for residents 
who are not prepared," said the administrator of Garda Caah, Riki Waskito. Garda Caah is a volunteer organization whose members are residents of Majalaya District with the aim of anticipating the impact of flooding in the area.

Ironically, even though they have lived with floods for decades, residents are still worried when the rainy season arrives as their life is at stake. Reflecting on this, it is imperative for residents to be able to minimize the possibilities and impacts of a disaster. Good communication among the concerned and involved parties appears to be a solution to this issue. Through good communication, those affected by disasters can gain an understanding of disasters. The problem is that the process of organizing messages carried out by the government and private institutions overlaps. The issue of coordination is still shackled by a rigid bureaucracy. Governments with their own regulations, and those who want to help on the other hand, often make their own work programs that are not well coordinated. Sometimes even political parties join in fishing in the murky water of the disaster. In a situation like this, information about the disaster becomes mixed. Examples of cases in the number of victims. If we look closely at the flow of information, it is without governance and not properly integrated. In fact, in these conditions, information is very important to reduce the impact of a disaster. As explained by Frank Dance (in Littlejohn \& Foss, 1998), "one important aspect of communication is the concept of uncertainty reduction". Communication exists to reduce uncertainty, in order to act effectively to protect or maintain the ego concerned in interacting individually or in groups. The presence of the community in anticipation of disasters is interesting to observe. Citizen participation is a key principle of disaster risk reduction and building resilience. However, in most developed countries, emergency and disaster management rely largely on a workforce of professionals and, to varying degrees, volunteers affiliated with official agencies. Individuals and groups who work outside of this system have tended to be viewed as a nuisance or liability, and their efforts are often undervalued. Given increasing disaster risk worldwide due to population growth, urban development and climate change, it is likely that 'informal' volunteers will provide much of the additional surge capacity required to respond to more frequent emergencies and disasters in the future (Whittaker et al., 2015). The community of garda caah (flood guard) who is present in the flooded areas along the Citarum watershed is an alternative for residents to share information about flooding. Preventive efforts can be done well. With the motto "Hope for the best and prepare for the worst," they are always aware of the possibility of flooding. This is what can ultimately reduce the impact of a major disaster.

\section{LITERATURE REVIEW}

Learning to manage disasters in the Garda Caah community involves several concepts or theories, including the concept of learning, the concept of community empowerment, and the theory of communication management. Dissemination of information about floods is carried out through various media commonly used by the public, both traditional and modern channels.

The concept of learning in anticipating floods in the Garda Caah community is essentially a learning process for residents of Bandung Regency as residents whose areas are affected by floods. This disaster is a recurring event: past, present and future. Epskamp and Boeren said "learning is a very ordinary affair," meaning that learning can be anywhere and anytime. Furthermore, they stated that "Our learning by schooling, for example, is planned. But we are not only well-educated but brought up in a proper way as well. Learning by way of upbringing is less planned and organized than learning by schooling. And besides these two 
ways, we learn by all our daily observations. Learning then refers to the degree of intention to receive information" (Epskamp \& Boeren, 1992). Therefore, facing the recurring flood disaster, throughout their lives, residents of Bandung Regency learn and the learning context here, as expressed by Epskamp and Boeren, is not formal learning in school, because in fact it is not like in Japan where realizing that it is a country with high disaster risk, the government The Japanese include this in their curriculum. Educational policies, students" background (social and economy) and how important the subjects for the future are part of aspects should be understood to support the good learning (Ahmadi \& Yanuarti, 2020).

But in Indonesia, this is still a dream. Therefore, the concept of non-formal learning is a necessity which is the only choice of Bandung Regency residents. They study how nature "creates" floods by studying various observable phenomena and finally they are able to predict when and how "excess water" they will receive. According to Bandung Spirit Coordinator Acil Bimbo, people in disaster-prone areas should be encouraged to help themselves if a natural disaster occurs in their area. This must be done to support mitigation measures to reduce the number of victims or losses due to natural disasters. According to Acil, currently, the community's dependence on local government and community social institutions is still very strong, especially in handling disaster mitigation, emergency response, and post-disaster. The reason is the lack of public understanding of the potential for disasters in the area where they live.

Related to this, the people of Bandung Regency empowered themselves by clustering the Garda Caah Community. According to Horton, a society is a group of people who are relatively independent, who live together for a long time, inhabit a certain area, share the same culture, and carry out most of their activities in that group. Furthermore, Soerjono Soekanto detailed the elements of society as follows; (1) Humans who live together, (2) They are mixed for a long time; (3) They are aware as a unit; and (4) They are a system of living together. Soekanto interprets society as a community (Satria, 2015). Along with a new perspective on development that increasingly involves the community, participatory approaches and community empowerment are increasingly being explored. This understanding is important because grassroots people who are faced with threats are not defenceless as constructed by the technocrats. Disaster risk reduction at the grassroots level that is born from the awareness of the capacities of local communities and their priorities makes them sustainable.

The concept of empowerment according to Adimiharja and Hikmat is not only individually but collectively (individual self-empowerment and collective self-empowerment), and all of this must be part of self-actualization and co-actualization of human and human existence (Adimiharja \& Hikmat, 2004). Community empowerment shows a proactive attitude of the citizens, a growing awareness of the idea, in other words, the residents are the initiators. Benjamin Franklin long ago recognized the power of engaging learning. He confidently stated 'Tell me and I forget, Teach me and may remember, Involve me and I learn'. There is a common thread between learning and getting involved. In the context of disaster management, this means that disaster management work is carried out by and together with the community in which they play a key role from planning, design, implementation, monitoring, to program evaluation. It is agreed that in this concept the community is the main actor who makes and implements important decisions in relation to disaster management. Some communities around the world, have long been close and 'live with disaster risk'. 
The concept of Communication Management is explained by Michael Kaye that how the process of involving oneself to understand and understand others is to try to build understanding in communication, "How people manage their communication processes through construing meanings about their relationships with others in various settings" (Kaye, 1994). The context of communication in this study includes interpersonal communication, interpersonal communication, organizational communication and the use of communication technology.

\section{METHODOLOGY}

This study used qualitative research methods. Qualitative research is examining things that are in their natural environment trying to understand or interpret phenomena based on the meanings that people give to these things. Conventionally qualitative methodologies tend to be associated with the desires of researchers to examine the meaning, context, and a holistic approach to phenomena. formulation of the problem studied may also be discovered only after collecting data in the field: the research instruments are usually unstructured (they are only a general guideline for the depth-interview, which can be developed according to the conditions in which the interviews were conducted) (Hidayat, 2002).

Case studies are one type of qualitative research. Unlike the other types, case studies intensively analyze and describe a single unit or a system based on space and time. The topics normally examined in case studies are individuals, events, or groups. Through case studies, researchers are also expected to be able to gain an in-depth understanding of the situation and meaning that surrounds it. The case study design that the researcher applied in this study was a single case design because it only examined the communication of peripheral communities in alleviating natural disaster problems. In order to get accurate data, the researchers conducted interviews with informants namely Riki Waskito as the Garda Caah coordinator and Rahmat as the Jaga Balai coordinator and representatives of related institutions.

\section{RESULTS AND DISCUSSION}

When the presence of the state in disaster protection is felt to be lacking, the presence of the community of citizens in disaster management efforts should be appreciated. Garda Caah is a community moved with concern in dealing with floods. "If you wait for the government, when?" The sentence that came from Riki as the initiator of this community, indicates that residents are not resigned but are helpless in facing disasters. Hoping for the best, preparing for the worst as Garda Caah's motto is certainly not without purpose. If so far residents have been more concentrated on disaster management, this community strives to prevent large numbers of victims by anticipating the possibility of a disaster. Learning from the signs of nature has made residents aware that living side by side, in harmony, in balance with nature is a necessity for a better life. This is a form of community participation. Opinion community participation has different meanings so it is necessary to clarify which process can be called participation so that there is a common view in assessing past, present, and future participatory processes (Ahmadi et al., 2019). Based on exploration and observations in the field, researchers can finally build a Participatory Communication Management that explores the communication skills of the Garda Caah community in terms of (1) Initiation, namely a youth meeting with ideas about anticipation and flooding in Majalaya; (2) Forming, namely the youth organization called Garda Caah; (3) Negotiation, collaborating with various authorities and competent parties in the field of flood disaster; (4) Optimizing stakeholders, 
namely establishing cooperation at the local level, with residents so that they are ready, have the ability to anticipate floods.

\section{Establishment of Garda Caah}

Community is the differentiating factor for disaster events. An event that is caused by natural, non-natural or social conditions is usually only referred to as a disaster when it causes an impact that disrupts the functioning of a community so as to cause physical, social, economic loss and such that the community concerned will not be able to. handle it with its own resources. The status of community empowerment is a determining factor for the occurrence of a disaster or not, or at least the severity of its impact. Following this logic, the community is also the basic unit in which investment in disaster management should be made. Whereas district to national units are the aggregate of community risks at the local level so that the actual practice of disaster risk reduction is at the community level. Communities are also bound by the "social capital" described by Putnam (2000), as interpersonal relationships, namely social networks and reciprocity and mutual trust. For example, a community of one village living in the same geographic environment, exposed to recurring hazards and disaster risk - has the same crisis experience: equal risk provides an increased sense of co-existence (Paripurno \& Jannah, 2014). This is also what initiated the establishment of the Garda Caah community in Majalaya.

Majalaya is a sub-district located in Bandung Regency. This area is famous as an industrial centre in West Java, Indonesia. The number of factories has had an impact in the form of damaged river habitats that make flooding seem like an annual "ritual". This flood routine in Majalaya area is what makes some young people who are part of the nature lover group try to find a solution.

The initial history of flood victims around Majalaya has been breathless and upset because every year the floods impact material, psychological, and even mental losses. With that background, we are moved to find a solution so that Kondang Village, Majalaya District, Bandung Regency is not flooded, explained Riki.

We who are from an environmental background and love to go up the mountain agreed to meet. At that time, we were still in Sasak Kondang, a group of youth in Kondang Village, Majalaya, who liked outdoor activities, he said.

It is named Sasak (Sundanese) which means bridge because dozens of young men live in a village adjacent to Majalaya Bridge. The bridge crosses the Citarum River. The group, founded in 2002, was the forerunner of the establishment of the Garda Caah. Caah (Sundanese) means flood, so Garda Caah means flood guard.

In 2007 the meeting between youth groups intensified. Majalaya Sasak Kondang youth then joined the Communication Forum of Nature Lovers of Bandung Regency. "Our spirit was fiery, inspired by wanadri's Gladian Panji Geografi training," said Riki, one of the pioneers of the establishment of the Garda Caah. One group in Majalaya and Bandung regency joined forces, such as Komunitas Peduli Lingkungan, Generasi Muda Majalaya, and Nature Lovers Leuwidulang-Majalaya. On 1 November 2008, Garda Caah was born. 


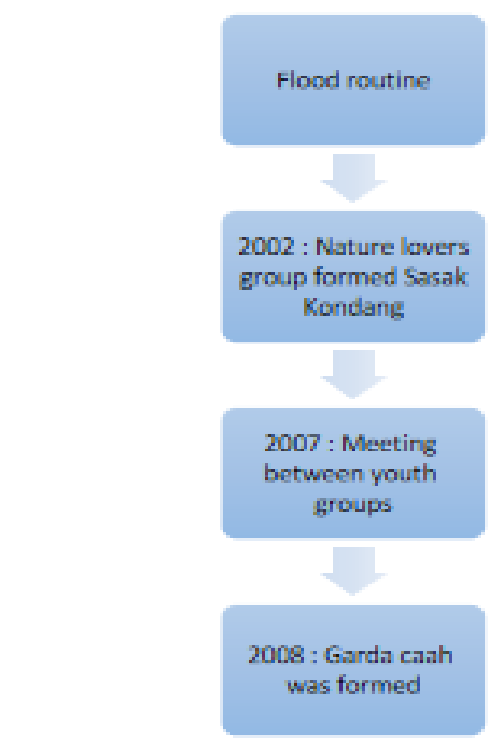

background of the establishment of the garda

caah

Figure 1: Backgroud of the establishment of the Garda Caah

Flood Management: Learning With Garda Caah Community

Majalaya area is a flood-affected area with a disaster character that is different from other flood-affected areas. Majalaya is affected by floods or flash floods. Researchers have difficulties coming to the research site. One of which was because Majalaya was flooded so isolated that the transport to the area was almost closed. Only mid-June researchers were able to enter the area. On our observations in the field at the time, researchers saw the consequences of flooding, mud and water still visible in some places, the remnants of flooding are still visible everywhere. When it rains, it is a thrilling time for Majalaya people. They cannot sleep comfortably and quietly, because if the rain comes at night, then bedtime can be a time to 'be alert' to flooding. That is what they went through all their lives there; a sense of caution, not calm even fear of having to constantly face them. On the other hand, they cannot and do not want to move. A lot of things are being considered. It was said by Riki, coordinator of Garda Caah that Majalaya only received water shipments from various rivers that covered their territory. In Majalaya, economic and social activities are going well, so residents are reluctant to move. Therefore, relocation is not an option for residents. Consequently, they should be able to come to terms with flooding, so they learn to manage disasters so they can keep living a normal life. Learn to receive floods as part of their lives, and importantly how to manage them by anticipating them. This learning phenomenon is categorized as 'out of school' education. Anderson (Epskamp \& Boeren, 1992) referred to it as "informal education; the truly lifelong process whereby every individual acquires attitudes, values, skills, and knowledge from daily experience and the educative influences and resources in his or her environment".

The understanding and awareness that their environment will always deal with flooding make residents adapt to the rhythm and preparedness of the disaster. This motivated the young people to form a disaster container that they named Garda Caah. These young men 
then volunteered to optimize their material and non-material resources, as well as looking for others who were more competent. They also spread flood anticipation information to residents. It can be said that these volunteers do 'self-manage flood anticipation' which can be presented in the form of the following image:

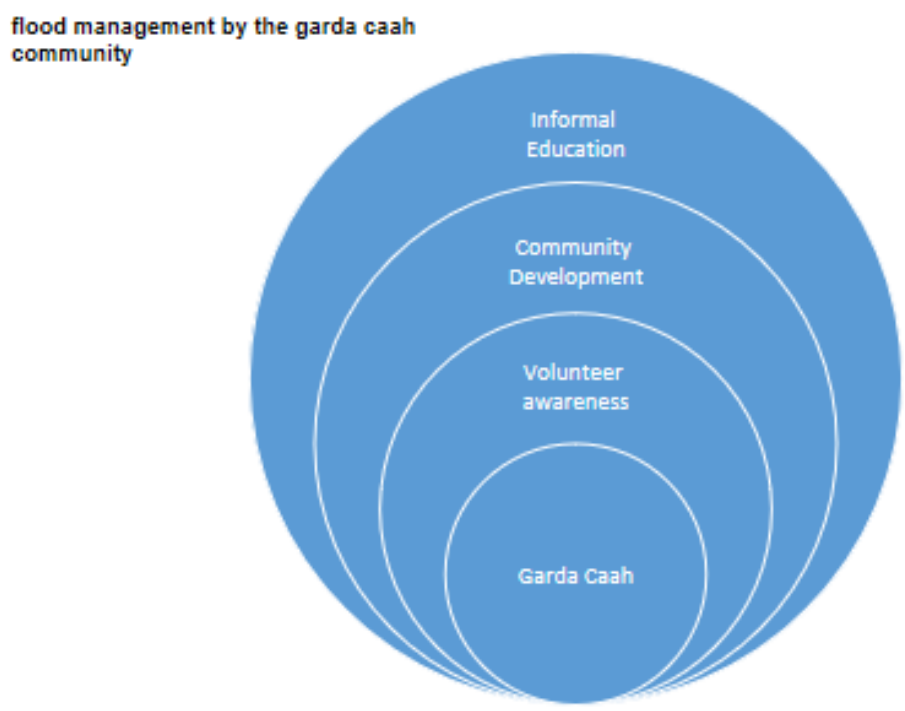

Figure 2: flood management by the garda caah community

The brief description above how disasters that are usually feared and become a terrible scourge for the people, can be accepted by the Garda Caah community as part of their life and do not become a major obstacle that hinders their daily lives. In fact, disaster does not make them weak creatures who accept mercy.

\section{Information-Based Guard Operations}

The operation of Garda Caah is relatively simple, which is based on strengthening information. The number of volunteers at that time was 60 people, getting ready in their homes and areas. The information channel that was built was between volunteers in the upstream and downstream parts of the Citarum. Which includes the upstream area, namely Pacet, Ibun, Kertasari and Cibeureum. Meanwhile, the downstream areas are Majalaya and Ciparay.

If it rains heavily in the upstream area for more than two hours, the volunteers in the upstream inform the volunteers downstream. This means that floods will come and downstream residents are asked to be ready to evacuate and not to be careless, said Riki.

The information was conveyed via text message on a cell phone. The downstream recipients spread the word and set a security status. "If the upstream is given alert, we are the downstream, too. The status in the downstream is made higher so that there is extra preparation for the worst possibility of flooding, "he said. Information about the arrival of floods from the upstream is unlikely to be wrong because volunteers in the upstream also coordinate with the field officers of the Bandung Regency Water Resources Management (PSDA), who monitor Citarum water level in Majalaya. Adang Suhendar, the name of the officer, always informs Garda Caah every time the water level of the Citarum River rises. In its 
operation, the youths took the Indonesian Interpopulation Radio Local IV, Majalaya Region. A number of local figures and entrepreneurs also helped by donating 11 handy-talkies. The tools were distributed to youths who lived in four vulnerable villages in Majalaya, namely Majalaya, Majakerta, Majasetra, and Sukamaju. After the volunteers learned about the conditions in the field, they passed it on to the village, RT, and RW leaders, the smallest unit of government in Indonesia. All residents are advised to be on standby to evacuate their belongings or install sand embankments. On several occasions, the elderly are forgotten.

The initial objective was to provide information so that residents would be prepared and reduce casualties, said Riki about the basic objectives of the flood guard.

The efforts of Riki and friends were not in vain. In the big flood on November 12, 2008, for example, there were no casualties and the residents were minimally injured. Residents are already sacking sand or leaving the house when the flood arrives. As a result, 4,231 residents of the sub-district survived, even though the mud was up to one meter high at some points. The mudflow was the biggest in Majalaya, after 1986. Knowing the crucial role of young people in anticipating floods, Riki and his friends in Garda Caah entered the realm of education. He participated in socializing the importance of maintaining the cleanliness and preservation of the Citarum to school students. In every socialization, he made a brochure or pamphlet containing brief information about Citarum and simple things that residents can do.

The habit of littering, for example, there are still many people littering into the river. My neighbour once warned me, but because he didn't accept it, he even wanted to beat me up, said Riki reminiscing.

For operational purposes and outreach to residents, Riki and friends raised funds from their personal pockets.

With limited funds and time, the Garda Caah operation must continue. The division of tasks among members is the key, he said.

In its development, Garda Caah has established communication and cooperation with several institutions outside of Majalaya, namely the Bandung Institute of Technology (KKSA ITB) Atmospheric Science Expertise Group and PT Reasuransi Maipark Indonesia in a community-based flood risk reduction initiative program. Now, Garda Caah has been assisted by better technology and information systems by procuring an automatic weather variable recorder or Automatic Weather Station (AWS) and an automatic water level recorder (AWLR).

Especially with the era of information technology and social media, it is very helpful to disseminate information for early warning, he said.

Before using the ARG weather monitoring tool and the AWLR river water level monitor, Garda Caah Majalaya volunteer in monitoring the weather using manual methods and observing weather conditions in the upstream area of the Citarum River, said volunteer Garda Caah Majalaya, Riki Waskito. 
For manual weather monitoring, he said, the volunteers always used a password. For example, mentioning the code name hileud Bulu is a sign of drizzling rain, hileud is a sign of moderate rain, hileud is a sign of heavy rain. According to him, weather monitoring includes observing weather conditions towards the upper reaches of the Citarum River, which is in the southern part of the Kertasari area. Weather monitoring began in 2003 and has been increasingly intense in monitoring.

We formed an emergency response codenamed Operation Caah Guard, he said.

According to him, with the formation of this emergency response, starting in 2008, it began to inform the public about weather conditions. But at that time, it was still limited to the public. Stepping on 2010 and 2011, major floods began to occur in the Majalaya area.

On the basis of this incident, we are trying to predict the local weather which includes Majalaya, Ibun, Paseh, Pacet and Kertasari. The local weather monitoring is to determine weather conditions that have the potential to cause overflows or floods, he said.

Weather monitoring also includes going to the field and seeing the conditions of rainfall and river flow. When seeing the potential flood conditions, then disseminated it to the community via short messages. However, weather observation and information systems, which were initially simple and traditional, have now changed to a more modern one with better predictability and accuracy. Decision-making in emergencies requires a non-traditional approach and tools characterized by non-hierarchical structure and flexibility. The dynamic environment of disasters makes it imperative to invest in inter-sector and inter-agency cooperation and coordination (Kapucu \& Garayev, 2011).

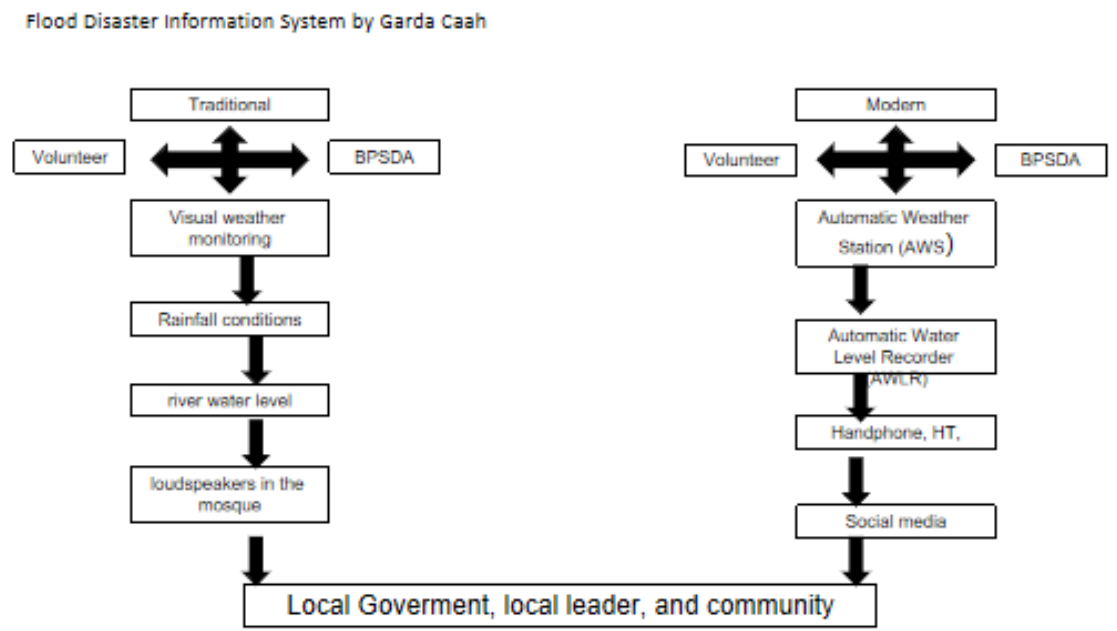

Figure 3: Flood Disaster Information System by Garda Caah

Even though it was helped by modern equipment but the understanding of disasters among residents was still low, for this reason, around May 2016 a training on disaster mitigation of land movement was carried out by community administrators of Garda Caah 
and Jaga Balai and Disaster Care Community Group (KPMB). On this occasion, Garda Caah invited other communities in Bandung Regency to discuss Disaster Early Warning Technology. Flood-affected areas such as Bale Endah, Dayeuh Kolot and Bojong Soang were also involved. Riki Waskito as the caretaker of Garda Caah said that "Disaster education, especially community early warning systems, needs to be disseminated." "Dissemination of disasterrelated information needs to be carried out by all parties," he added. . Local values are an important characteristic of effective communication during the disaster mitigation process. It is very important to practice communication that is characterized by respect, sincere attitude and dignity (Mustaffa, et. Al., 2018).

Therefore it is necessary to manage communication involving all elements as illustrated below:

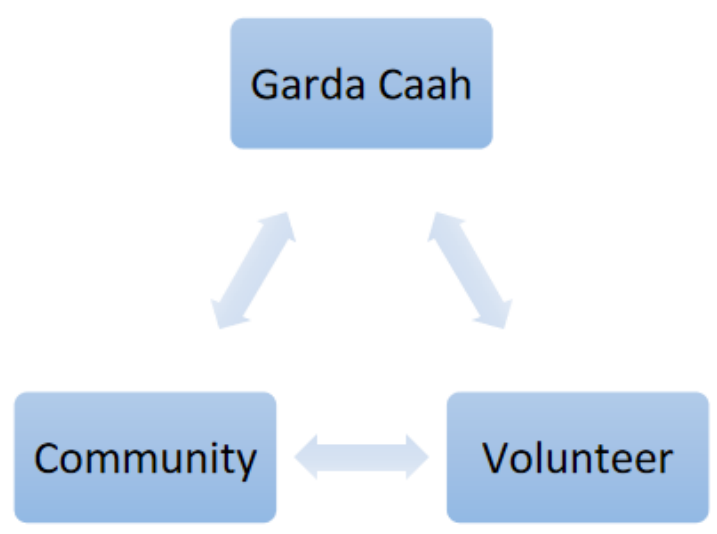

Figure 4: Circulation of information and communication by Garda Caah

\section{CONCLUSION}

Disaster is inevitable; however, reducing losses due to disasters is a doable action. Indonesia as a country with a high level of disasters anticipates this by making Law no. 24 of 2007 concerning Disaster Management, especially Article 4 where respecting local culture and building participation and partnerships with the public is the goal of disaster management. The management of information among various stakeholders in natural and human-induced disasters is fundamental to the mitigation and effective disaster-relieve operations. Efficient information exchanges are a vital component of disaster response and relief operations. This is based on the idea that precise and timely information is made available prior, during and after disasters. Disasters always happen abruptly, and often with different levels of severity, posing a major challenge for effective information exchanges and coordination (Moorthy et al., 2018). Management of communication and delivery of information related to flood early warning carried out by Garda Caah, although currently using modern methods and devices such as smartphones, the use of traditional equipment such as mosque loudspeakers are still used. The language used is adjusted to the device used. If using a smartphone, Indonesian is used, but if the information is conveyed via mosque loudspeakers, Sundanese is used. The use of different languages is adjusted to the characteristics of media users where smartphones are mostly used by young people while information via mosque loudspeakers uses Sundanese because of socio-cultural considerations where many older people are more comfortable and feel valued if the information is conveyed in Sundanese. 
The conclusions of this study are: (1) The learning process for the Garda Caah disaster is self-management in anticipation of floods that covers an informal learning process, empowering its residents with the spearhead of volunteers; (2) There was a transition from the disaster information system, which was originally local and traditional, to rely on technology in collaboration with various competent authorities; (3) The Garda Caah community in anticipating flooding relies on participatory communication management based on the aspects of initiation, formation, negotiation and optimization of stakeholders.

\section{ACKNOWLEDGEMENT}

We give our gratitude to the Dean of Faculty of Communication, Universitas Islam Bandung (UNISBA), Indonesia, and the academic supervisor at the Faculty of Communication Science, Universitas Padjadjaran (UNPAD), Indonesia.

\section{BIODATA}

Mochamad Rochim is a senior Lecturer at Faculty of Communication, Universitas Islam Bandung. Currently pursuing doctoral studies at the Faculty of Communication Sciences, Padjadjaran University. His research interests include community, radio, management communication, communication disaster. Email: mochammad.rochim@unisba.ac.id

Atwar Bajari is a Senior Lecturer at Faculty of Communication, Universitas Padjadjaran Jatinangor, Indonesia. His research interests include medium, metodologi, etnografi. Email: atwar.bajari@unpad.ac.id

Ninis Agustini Damayanti is a senior Lecturer at Faculty of Communication, Universitas Padjadajran Jatiangor, Indonesia. Her research interest included Pemasaran, informasi, Media \& Budaya, Literasi \& Komunitas, Komunikasi Kebencanaan. Email: ninis.agustini@unpad.ac.id

Iriana Bakti is a senior Lecturer at Faculty of Communication, Universitas Padjadajran Jatiangor, Indonesia. His research interest included Komunikasi Lingkungan. Email: irianabaktipr@gmail.com 


\section{REFERENCES}

Adimiharja, K., \& Hikmat, H. (2004). Participatory research appraisal dalam pelaksanaan pengabdian kepada masyarakat. Bandung: Humaniora.

Ahmadi, D., Rachmiatie, A., \& Nursyawal. (2019). Public participation model for public information disclosure. Jurnal Komunikasi: Malaysian Journal of Communication, 35(4), 305-321. https://doi.org/10.17576/JKMJC-2019-3504-19

Ahmadi, D., \& Yanuarti, E. (2020). Reflective writing: Students' diaries to improve the teaching and learning process. Proceedings of the 2nd Social and Humaniora Research Symposium (SoRes 2019) (pp. 521-524). https://doi.org/10.2991/assehr.k.200225.113

Epskamp, K. P., \& Boeren, A. J. J. M. (1992). The empowerment of culture: Development, communication, and popular media (CESO paperback). The Hague, Neverland: Centre for the Study of Education in Developing Countries.

Hidayat, D. N. (2002). Metodologi penelitian dalam sebuah "multi-paradigm science." Mediator: Jurnal Komunikasi, 3(2), 197-220. https://doi.org/10.29313/mediator.v3i2.766

Kapucu, N., \& Garayev, V. (2011). Collaborative decision-making in emergency and disaster management. International Journal of Public Administration, 34, 366-375.

Kaye, M. (1994). Communication management. Sydney: Prentice Hall.

LittleJohn, S. W., \& Foss, K. A. (1998). The theories of human communication (10th ed.). Illinois: Waveland Press.

Moorthy, R., Benny, G., \& Gill, S. S. (2018). Disaster communication in managing vulnerabilities. Jurnal Komunikasi: Malaysian Journal of Communication, 34(2), 51-66.

Mustaffa, C. S., Marzuki, N. A., Khalid, M. S., Sakdan, M. F. \& Sipon, S. (2018). Understanding Malaysian Malays communication characteristics in reducing psychological impact on flood victims. Jurnal Komunikasi: Malaysian Journal of Communication, 34(1), 20-36.

Paripurno, E. T. \& Jannah, N. M. (2014). Panduan pengelolaan risiko bencana berbasis komunitas. Yogyakarta: Deepublish.

Putnam, R. D. (2000). Bowling alone: The collapse and revival of American community. New York: Simon and Schuster.

Rochim, M., Bajari A., Damayanti, N. A., \& Bakti, I., (2019) Early warning system model as a resilience of disaster-prone communities. Journal of Physics: Conference Series, 1375, 012093. https://doi.org/10.1088/1742-6596/1375/1/012093

Undang-Undang Republik Indonesia. (2017). Undang-undang nomor 24 tahun 2007 tentang penanggulangan bencana 1 . Retrieved from https://bnpb.go.id/produkhukum/undang-undang/undang-undang-no-24-tahun-2007

Satria, A. (2015). Pengantar sosiologi masyarakat pesisir. Jakarta: Yayasan Pustaka Obor Indonesia dan Fakultas Ekologi Manusia IPB.

Sinaga, T. M. (2020). Warisan usang banjir tiada akhir. Kompas National Newspaper, 11.

Whittaker, J., McLennan, B., \& Handmer, J. (2015). A review of informal volunteerism in emergencies and disasters: Definition, opportunities and challenges. International Journal of Disaster Risk Reduction, 13, 358-368. https://doi.org/10.1016/j.ijdrr.2015.07.010 